\title{
Laparoscopic versus open splenectomy in $\operatorname{dog} \mathbf{s}^{1}$
}

\author{
Rafael Stedile ${ }^{2}$, Carlos A.C. Beck ${ }^{2}$, Fabiana Schiochet ${ }^{2}$, Márcio P. Ferreira ${ }^{2}$, \\ Simone T. Oliveira ${ }^{2}$, Fernando B. Martens ${ }^{2}$, Jardel P. Tessari², Sheila B.L. \\ Bernades $^{2}$, Carolina S. Oliveira ${ }^{2}$, Andrea P. Santos ${ }^{3}$, Fabíola P.S. Mello², \\ Marcelo M. Alievi ${ }^{2}$ and Marcelo S. Muccillo²
}

\begin{abstract}
Stedile R., Beck C.A.C., Schiochet F., Ferreira M.P., Oliveira S.T., Martens F.B., Tessari J.P., Bernades S.B.L., Oliveira C.S., Santos A.P., Mello F.P.S., Alievi M.M. \& Muccillo M.S. 2009. Laparoscopic versus open splenectomy in dogs. Pesquisa Veterinária Brasileira 29(8):653-660. Faculdade de Veterinária, Universidade Federal do Rio Grande do Sul, Av. Bento Gonçalves 9090, Porto Alegre, RS 91540-000, Brazil. E-mail: stediler@gmail.com

In the last few years, the use of laparoscopy in veterinary medicine has expanded and consequently so was the need for studies that establish the advantages, disadvantages and possible complications of each procedure. The purpose of the current study was to describe a laparoscopic splenectomy technique and the alterations due to this access, and compare it to the open procedure in dogs. A total of 15 healthy female mongrel dogs were used, with mean weight of $17.4 \pm 2.5 \mathrm{~kg}$. The animals were distributed into three groups: Group IA of open splenectomy (laparotomy) using double ligation of the vessels of the splenic hilum with poliglicolic acid, Group IB of open splenectomy (laparotomy) with bipolar electrocoagulation of the splenic hilum, and Group II of laparoscopic access with bipolar electrocoagulation of the splenic hilum. Operative time, blood loss, size of incisions, complications during and after surgery were evaluated. Other parameters included pain scores, white blood cell (WBC) counts and postoperative serum concentrations of alanine aminotransferase (ALT), alkaline phosphatase (ALP), creatine kinase (CK), C-reactive protein (CRP), glucose and cortisol. No differences were found in the evaluation of parameters between both open splenectomy techniques employed. Laparoscopic access presented significant differences $(p<0,05)$ when compared with open surgery: Longer operative time, smaller abdominal access, decrease in blood loss, lower concentrations of CRP, higher levels of CK and ALP, and lower scores in the pain scale. Laparoscopic surgery showed fewer complications of the surgical wound. No significant differences were observed between groups in the postoperative temperature, WBC, ALT, cortisol and glucose concentrations. In conclusion, the laparoscopic technique is useful for splenectomy in dogs, being advantageous in terms of blood loss, surgical stress and surgical wounds. However, it expends more operative time and causes transitory increase in hepatic and muscular enzymes.
\end{abstract}

INDEX TERMS: Spleen, minimal invasive surgery, enzymes, stress, pain.

RESUMO.- [Comparação entre esplenectomia laparos-
cópica e convencional em cães.] Nos últimos anos, a
utilização da laparoscopia em Medicina Veterinária vem

\footnotetext{
${ }^{1}$ Received on March 20, 2009.

Accepted for publication on May 5, 2009.

2 Faculdade de Veterinária, Universidade Federal do Rio Grande do Sul, Av. Bento Gonçalves 9090, Porto Alegre, RS 91540-000, Brazil. *Corresponding author: stediler@gmail.com

3 Department of Comparative Pathobiology, Purdue University, 725 Harrison Street, West Lafayette, IN 47907, USA.
}

expandindo e, conseqüentemente, a necessidade de pesquisas que determinem as vantagens, desvantagens $e$ possíveis complicações de cada procedimento. Este estudo teve como objetivo descrever uma técnica de esplenectomia laparoscópica, assim como as alterações decorrentes deste acesso, e compará-la ao procedimento convencional em cães. Foram utilizadas 15 cadelas hígidas, sem raça definida, com peso médio de 17,4 $\pm 2,5 \mathrm{~kg}$. Os animais foram distribuídos em três grupos: Grupo IA de acesso convencional (por laparotomia) utili- 
zando ligadura com ácido poliglicólico no selamento vascular do hilo esplênico, Grupo IB de acesso convencional (por laparotomia) com eletrocoagulador bipolar do hilo esplênico, e Grupo II de acesso laparoscópico com eletrocoagulador bipolar para selamento vascular dos ramos esplênicos. Estes grupos foram avaliados em relação ao tempo cirúrgico, à perda de sangue, ao tamanho das incisões e às complicações durante e após a cirurgia. Também foram comparadas as avaliações da escala de dor e as alterações no leucograma e nas concentrações séricas da alanina aminotransferase (ALT), da fosfatase alcalina (FA), da creatina quinase (CK), da proteína C-reativa (CRP), da glicose e do cortisol no pós-operatório. Os acessos convencionais não diferiram entre si nos parâmetros avaliados. O acesso laparoscópico apresentou diferenças significativas $(p<0,05)$ quando comparado ao convencional: maior tempo cirúrgico, menor acesso abdominal, diminuição na perda de sangue, menores concentrações de CRP, maiores níveis de CK e FA, além de pontuação menor na escala de dor. A cirurgia laparoscópica apresentou menor número de complicações das feridas cirúrgicas. A ALT, o cortisol, a glicemia, o leucograma e a temperatura retal pós-operatórias não diferiram significativamente entre os acessos convencional e laparoscópico. Conclui-se que a cirurgia laparoscópica é viável para esplenectomia em cães, apresentando vantagem em relação à perda de sangue, ao estresse cirúrgico e às feridas cirúrgicas, embora apresente maior tempo cirúrgico e cause aumento transitório de enzimas hepática e muscular.

TERMOS DE INDEXAÇÃO: Baço, cirurgia minimamente invasiva, enzimas, estresse, dor.

\section{INTRODUCTION}

In the last 30 years several techniques of laparoscopic access for abdominal and thoracic diseases have been developed. The advantages of the minimal invasive surgery (MIS) are lower postoperative stress and pain, lower morbidity, shortened hospitalization, fast recovery and minimal loss of blood (Freeman \& Potter 1998, Maluenda et al. 2004).

Clinical and experimental researches comparing open and laparoscopic surgeries were done to determine the advantages in each procedure (Domini et al. 1999, Braga et al. 2005, Katkhouda et al. 2005, Aziz et al. 2006, Hutter et al. 2006). Such comparison was not found in the literature in relation to splenectomy in dogs, although splenectomy is commonly performed in dogs (Hosgood et al. 1989). Indications for total splenectomy include tumors, benign splenic lesions, splenic torsion, traumatism and hematological imunomediated diseases not responsive to treatments with drugs (Harari 1999). The usual technique includes individual ligation of the short splenic branches of the splenic artery and vein, preserving the left gastroepiploic artery, and short gastric arteries (Hosgood et al. 1989). First report on laparoscopic splenectomy in humans was presented by Carril and colleagues in 1992 (Himal
2002), later being considered an excellent choice in cases of hematological diseases (Romano et al. 2002, Maluenda et al. 2004). More recently, laparoscopic splenectomy has been indicated in the treatment of malignant neoplasias in humans (Brodsky et al. 2002). Diagnosis and treatment of benign nodular hyperplasia were successfully done in a dog (Stedile et al. 2004). Recently, these authors also performed MIS in a dog with splenic hemangiosarcoma.

Conventional bipolar electrosurgery is used in open surgeries and MIS. Other methods of vascular sealing such as laser, ultrasonic energy, bipolar radiofrequency as well as modern plasma pulses have been developed; however, most of them are expensive (Richter et al. 2006). The use of bipolar electrocoagulation is well described in laparoscopic procedures in animals, mainly related to ovariectomy and ovariohysterectomy (Van Goethem et al. 2003, Van Nimwegen et al. 2005, Schiochet 2006), but it has also been described in case of splenectomies (Stedile et al. 2004, Oliveira et al. 2007). The purpose of the current study is to describe a laparoscopic splenectomy technique in dogs, as well as their alterations due to this access, and to compare this to the open procedure.

\section{MATERIALS AND METHODS}

After the Ethical Committee, Faculdade de Veterinária, Universidade Federal do Rio Grande do Sul, approval, a total of 15 healthy female mongrel dogs, with mean weight $17.4 \pm 2.5 \mathrm{~kg}$, were used. Dogs were considered healthy based on clinical examination, results of complete blood count and serum biochemical profile. The animals were distributed into three groups (five dogs each group): Group I of open splenectomy, Group IA of double ligation of the splenic hilum, Group IB of bipolar electrocoagulation of the splenic hilum, and Group II of laparoscopic access with bipolar electrocoagulation of the splenic hilum.

After a 12-hours fasting and water withheld for two hours, the same anesthetic protocol was utilized for all dogs. Acepromazine $(0.1 \mathrm{mg} / \mathrm{kg}$, IM) (Acepran $1 \% @$, Univet, Rua Clímaco Barbosa 700, São Paulo, SP) and petidine (3.5 mg/kg, IM) (Dolosal囚, Cristália Produtos Químicos e Farmacêuticos Ltda, Avenida Paoletti 363, Itapira, SP) were administered, followed by intravenous induction of anesthesia with propofol $(4 \mathrm{mg} / \mathrm{kg}$ ) (Provine $\AA$, Claris Produtos Farmacêuticos do Brasil, Rua Estados Unidos 242, São Paulo, SP). Anesthesia was maintained with isoflurane (Isoforine $\AA$, Cristália Produtos Químicos e Farmacêuticos Ltda, Avenida Paoletti 363, Itapira, SP) given through an endotracheal tube. Ampicilin $(25 \mathrm{mg} / \mathrm{kg})$ (Ampicilina Veterinária Injetável, Univet, Rua Clímaco Barbosa 700 , São Paulo, SP) was administered intravenously at induction. The animals were positioned in dorsal recumbence.

The spleen was accessed through a celitomy in Group I. After exposure of the spleen, proximal vessels of the hilum were isolated. In Group IA, the vessels were double ligated with poliglicolic acid 2-0 (Polycryl 2-0®, PolySuture Indústria e Comércio Ltda, Av. Gabriel Ramos da Silva 1245, São Sebastião do Paraíso, MG) and transected, initiating in the ventral portion. In Group IB, the occlusion of the vessels was done with a bipolar forceps of an electrosurgical system. The vascular sealing was done in three points, and the vessels were transected between 
them. Abdominal wall was sutured using 2-0 mononylon; subcutaneous tissue, using 2-0 poliglicolic acid; and skin, using 2-0 mononylon (Mononylon 2-0 Ethicon, Ethicon/Johnson \& Johnson, Rodovia Presidente Dutra 154000, São José dos Campos, SP). In Group II, a $10 \mathrm{~mm}$ incision was made in minilaparotomy midway, between the umbilicus and xiphoid process. After a $10 \mathrm{~mm}$ trocar insertion in the incision, the cavity was insufflated with $\mathrm{CO}_{2}$ until the $12 \mathrm{mmHg}$ intraabdominal pressure. A second trocar $(10 \mathrm{~mm})$ was inserted under laparoscopic guidance in the right abdominal wall, near the umbilicus. The telescope was relocated to the lateral portal. The third trocar $(5 \mathrm{~mm})$ was inserted under laparoscopic guidance, midway between the pubis and the umbilicus. Splenic hilum was exposed utilizing a Babcock forceps (10mm). The bipolar forceps electrocoagulator and Metzenbaum scissor were inserted in the caudal portal and used to coagulate and slip up splenic hilum vessels, respectively. The dog was inclined approximately 45 degrees to the right, when necessary, to improve access to the dorsal extremity of the spleen. An adapted retrieval bag for tissue removal was introduced through the cranial trocar and was held open using the grasped forceps. The spleen was introduced into the bag using the Babcock forceps. The trocar of the cranial portal was removed and the retrieval bag borders were exposed outside the cavity. The spleen was macerated into the bag using digital pressure and an Allis forceps, being removed in fragments. When necessary the incision was enlarged. The abdominal cavity was checked by visual inspection after the end of the procedure and the residual $\mathrm{CO}_{2}$ removed. At each portal, the abdominal wall was closed as described in open surgery.

The following defined surgical times were recorded: T1, from skin-incision to beginning of the manipulation of the spleen; T2, resection of spleen; T3, placing of the spleen in the bag and spleen maceration (only for Group II); T4, abdominal wall closure; Total surgical time $(\mathrm{T} 1+\mathrm{T} 2+\mathrm{T} 3+\mathrm{T} 4)$.

The blood loss was evaluated through the difference in the pre and postoperative sponge weight, considering $1 \mathrm{~g}=1 \mathrm{~mL}$. To estimate the blood loss, volemia at $8 \%$ was considered. The spleens were weighed and the splenomegaly classified as absent when the spleen weight represented $1 \%$ or less of the corporal weight; mild, at 1.1-1.5\%; moderate at 1.6-2.0\%; and severe, $\geq \square 2.1 \%$. Additionally, intraabdominal abnormalities and surgical complications were registered. At the end of the surgery, the incision size was measured in all groups.

Cetoprofen (2mg/kg) (Ketojet 100®, União Química Farmacêutica Nacional S/A, Rua Coronel Luiz Tenório de Brito 90, Embu-Guaçu, SP) and tramadol (2mg/kg) (Tramal囚, Pfizer Saúde Animal, Av. Monteiro Lobato 2270, Guarulhos, SP) were administered immediately after the surgery. Cetoprofen was administered once a day until the 2 nd day postoperatively. The wounds were cleaned and evaluated daily. After 30 days postoperative, laparoscopic ovariohysterectomy was done in all animals and the evaluation of postsplenectomy intraabdominal alterations was performed, observing principally the presence of intracavitary adhesions.

Serum concentrations of alanino aminotransferase (ALT), alkaline phosphatase (ALP), creatina kinase (CK), C-reactive protein (CRP) and cortisol were evaluated at 2, 6, 12, 24 and 72 hours after the end of the surgery. Glucose was evaluated in the same periods excluding the $72 \mathrm{~h}$. For the white blood cells (WBC) analysis, blood samples were collected preoperative, and after 3,15 and 30 days postoperative ( $\mathrm{K}_{3}$ EDTA tubes) (Tubos BD Vacutainer com $\mathrm{K}_{3}$ EDTA $®$, BD Brasil, Rua Alexandre Dumas 1976, São Paulo, SP). Serum ALP (Fosfatase alcalina Bioliquid®,
Laborclin, Rua Cassemiro de Abreu 521, Pinhais, PR), ALT (GPT Bioliquid@, Laborclin, Rua Cassemiro de Abreu 521, Pinhais, PR), and CK (CK Nac Bioliquid@, Laborclin, Rua Cassemiro de Abreu 521, Pinhais, PR) were measured spectrophotometrically with a semi-automatic analyzer using commercial kits; C-reactive protein (HumaTex CRP®, In Vitro Diagnóstica, Rua Cromita 278, Itabira, MG) was determined qualitatively and semi-quantitatively using a latex-agglutination immunoassay; cortisol (Elecsys Cortisol@, Roche Diagnóstica Ltda, Avenida Engenheiro Billings 1729, São Paulo, SP) was measured by electrochemiluminescence using an automatic analyzer; fresh whole blood glucose (AccuChek Go®, Roche Diagnóstica Ltda, Avenida Engenheiro Billings 1729, São Paulo, SP) was measured by reflectance photometry with a blood glucose meter (glucometer); and WBC count was performed with a semiautomatic cell counter.

The physical examination was done along with the study of behavior and temperament. Wound healing was classified as "infected" if purulent drainage, an abscess, or a fistula was recorded; as "infected/inflamed" when $\geq \square 3$ of the following signals were present simultaneously: redness, swelling, pain, heat, serous discharge, wound dehiscence.

The dogs were evaluated in relation to pain at 2, 6, 12, and 24 hours postoperatively, utilizing the University of Melbourne Pain Scale, according to Firth \& Haldane (1999). The preoperative values were taken as reference.

The statistical analysis was performed with computer software (SPSS Windows 15.0) using the ANOVA (analysis of variance), considering significance level of 0.05 .

\section{RESULTS}

Conventional accesses (Groups IA and IB) did not differ from each other in the evaluated parameters. Laparoscopic access (Group II) presented significant differences $(p<0.05)$ when compared to the open surgery: longer operative time, smaller abdominal access, and decrease in blood loss. Laparoscopic surgery presented smaller number of surgical wound complications.

The total surgical time differed significantly between Groups I (mean 51.5 \pm 5.5 minutes) and II (mean $115.4 \pm 13.6$ minutes). There was no difference between Groups IA (50.2 \pm 6.6 minutes) and IB ( $52.8 \pm 4.5$ minutes). The time for each procedure is showed in Fig.1.

Mean size of incision was $10.7 \pm 0.3 \mathrm{~cm}$ for Group IA, $10.1 \pm 1.1 \mathrm{~cm}$ for Group IB and $4.9 \pm 0.9 \mathrm{~cm}$ for the sum of the incisions of Group II.

Mean of spleen weight was $357.8 \pm 111.2 \mathrm{~g}$ (range, 149$552 \mathrm{~g}$ ). Six dogs presented severe splenomegaly; seven, moderate splenomegaly; and two did not present splenomegaly. One dog presented evidence of previous splenic trauma, with a scar in the splenic capsule, some splenic disseminations (splenosis) and adhesions of the omento in the capsule. Alterations in other organs were not seen.

The falciform ligament had to be removed in one dog (Group II) for better visualization of the spleen. In the same group, another animal suffered a small splenic lesion during the introduction of the first trocar, without significant bleeding, and another had the spleen capsule perforated by the Babcock forceps during the placing of the spleen in 


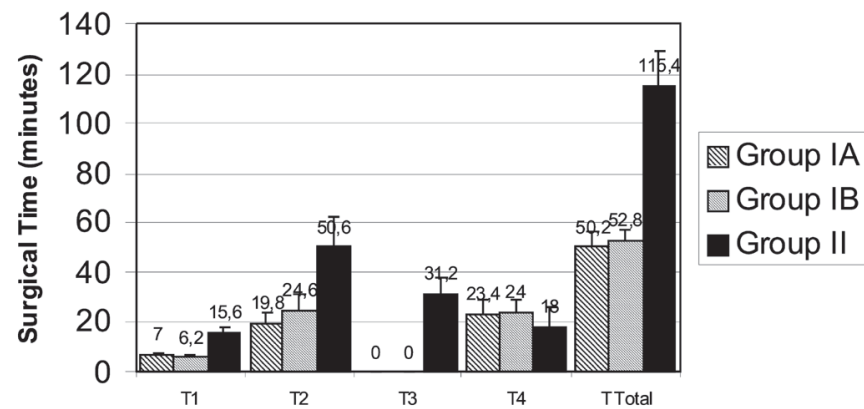

Fig.1. Mean values of surgical times (minutes). T1, from skinincision to beginning of the manipulation of the spleen; T2, resection of spleen; T3, placing of the spleen in the bag and spleen maceration (only for Group II); T4, abdominal wall closure; $\mathrm{T}$ Total, total surgical time $(\mathrm{T} 1+\mathrm{T} 2+\mathrm{T} 3+\mathrm{T} 4)$. Group I of open splenectomy, Group IA of double ligation of the splenic hilum, Group IB of bipolar electrocoagulation of the splenic hilum, and Group II of laparoscopic access with bipolar electrocoagulation of the splenic hilum.

the bag, causing a little bleeding in the abdominal cavity. A mean of 2.2, 3.4 and 1.4 bleeding episodes occurred in Groups IA, IB and II respectively, with no significant differences.

The proportion of blood loss to estimated individual volemia differ significantly $(p=0.002)$ between the laparoscopic group (Group II) (mean of $0.93 \%$ ) and conventional (Group I) (mean of 3.72\%). The blood loss did not differ significantly between Groups IA and IB. All animals presented decrease in rectal temperature during surgery. There was a relation between the temperature at the end of surgery $(p=0.002)$ and the animal weight $(p=$ 0.001 ). Temperature at the end of surgery was lower in the animals of smaller corporal weight and longer procedures, independent of the group.

Two dogs presented complications in the immediate postoperative period. One of them (Group IA) had a mild bleeding in the cranial portion of the skin incision. The other (Group II) presented moderate subcutaneous emphysema in the thorax and abdomen that initiated during the pneumoperitonium. Both were resolved without serious consequences. Group I presented three wounds (3/10 wounds) classified as infection/inflammation and one as infection $(1 / 10$

There was no significant difference in ALT levels either between Groups I and II, or within the groups, related to time. No statistically significant differences were found in ALP levels between Groups IA and IB, although it was found $(p=0.015)$ between Groups I and II. In Group II, there was significant difference at 12 and $24 \mathrm{~h}$ compared to preoperative and at 2 hours postoperative (Fig.2).

No significant differences were found in $\mathrm{CK}$ concentration between Groups IA and IB. There was lower concentration $(p=0.006)$ in Group I compared to Group II. In Group II there was a significant increase at 2, 12 and
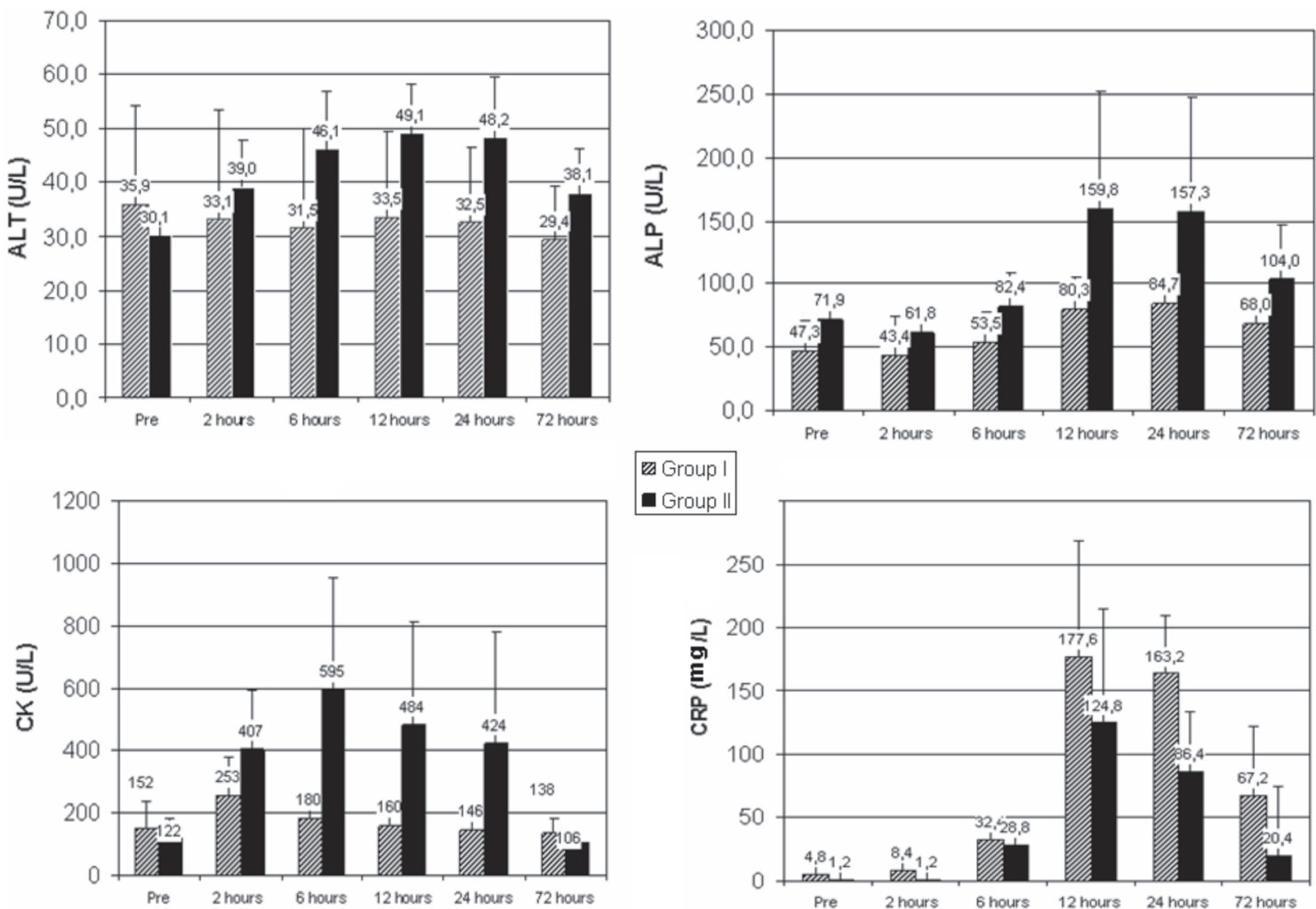

Fig.2. Mean values of alanine aminotransferase (ALT), alkaline phosphatase (ALP), creatine kinase (CK) and C-reactive protein (CRP) at preoperative and 2, 6, 12, 24 and 72 hours after the end of the surgery. Group I of open splenectomy, and Group II of laparoscopic access with bipolar electrocoagulation of the splenic hilum. 

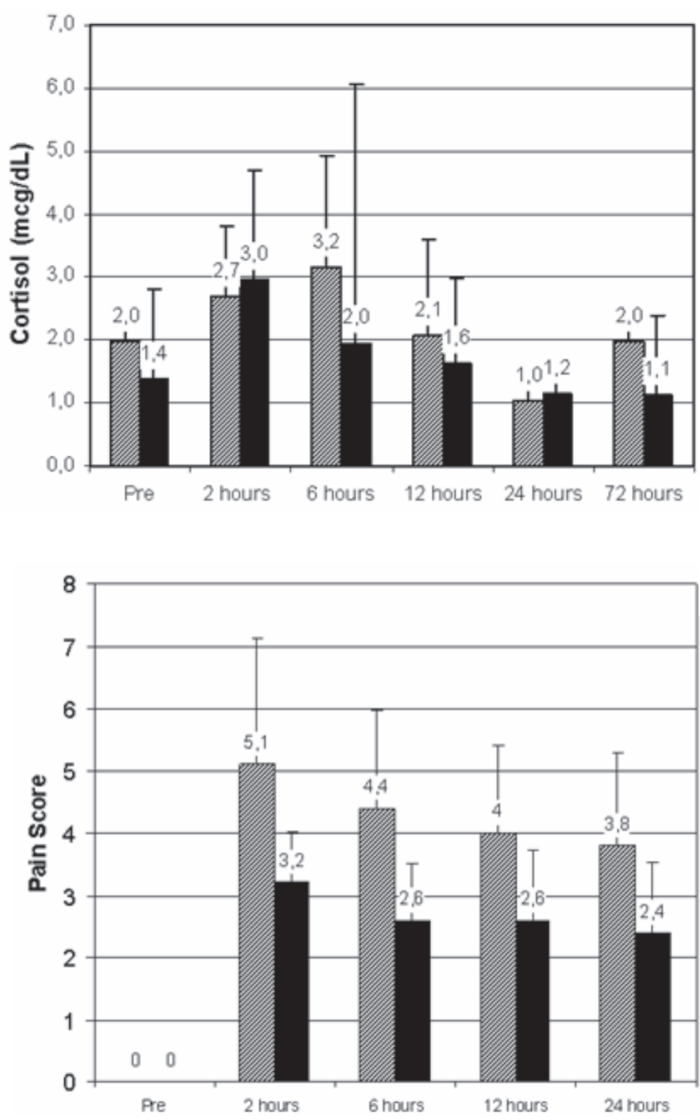

$24 \mathrm{~h}$ postoperative when compared to preoperative period and $72 \mathrm{~h}$ postoperative (Fig.2).

Postoperative CRP concentration was higher than preoperative in all groups. In Group II the concentration was lower $(p=0.03)$ than in Group I, being more evident at 24h postoperative (Fig.2). Postoperative WBC increased significantly in all groups.

Group I presented a higher $(p=0.004)$ punctuation in pain scale than Group II. The higher values occurred two hours postoperatively, but the difference between the groups was significant only at $24 \mathrm{~h}$. Serum cortisol and glucose concentrations showed no differences either between groups, or within the groups, related to the period of observation. Glucose and cortisol concentrations presented correlation only at six hours postoperative in all groups (Fig.3).

Laparoscopic evaluation (minimum 30 days postoperative) showed omental adhesions in seven dogs. In Group I, the omento adhered to ventral middle in the incision site in six dogs. Only one animal of Group II presented adhesions of omento at the site of telescope portal (right abdominal wall).

\section{DISCUSSION}

All the procedures were feasible, without the necessity of either conversion from laparoscopy to open procedure or the association with other forms of vascular sealing. The portal's position in laparoscopic technique promoted good

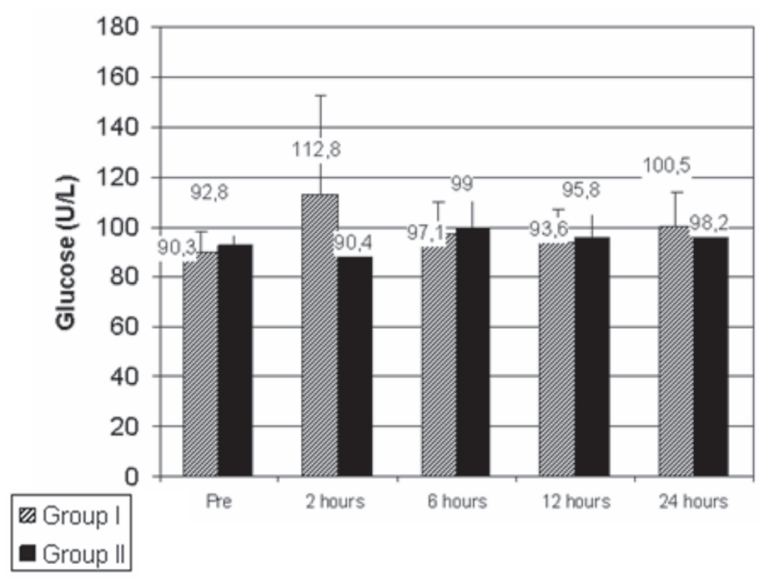

Fig.3. Mean values of cortisol, glucose and pain score at preoperative and 2, 6, 12, 24 and 72 hours (except 72 hours for glucose) after the end of the surgery. Group I of open splenectomy; Group II of laparoscopic access with bipolar electrocoagulation of the splenic hilum.

visualization, manipulation and exposure of splenic hilum, and a fourth portal was not necessary. The hilum vessels located in the ventral portion of the spleen were exposed and sealed more easily than those in the dorsal portion. Access to the latter needed a 45 degree inclination to the right in three of the five animals submitted to laparoscopic splenectomy.

The introduction of the first trocar using the open method is recommended, being advantageous compared to closed method, including reduction of iatrogenic lesion (Moberg \& Montgomery 2005). Nevertheless, one dog in the present study presented a small splenic lesion due to the introduction of the trocar using the open method, but repair was not necessary. In spite of this, the open method is considered safest to establish the pneumoperitoneum. The $12 \mathrm{mmHg}$ intraabdominal pressure used in this study was appropriate to the inspection of the cavity and realization of the splenectomies. However, we believe that lower pressures hindered the manipulation in cases of splenomegaly, principally during the introduction of the spleen into the bag.

Longer operative time observed in laparoscopic splenectomy when compared to conventional splenectomy was consistent with the reported literature in humans (Marassi et al. 1999, Sapucahy et al. 2003). Laparoscopic surgical times and complications tend to decrease with an increase in the level of the surgeon's experience, denominated learning curve (Higashihara et al. 1998, Harkki-Siren et al. 1999, Fraser et al. 2005). The number of laparoscopic procedures in our study did not permit the observation of learning curve; nevertheless we suppose that the time for laparoscopic splenectomy in dogs also decreases with more experience.

The placing of the spleen was considered as a difficult execution stage due to the relatively large size of the 
spleen, and flexibility and fragility of the capsule. The adapted bag was adequated to the spleen removal, and avoided the blood and spleen fragments extravasate during the removal. The use of an aspirator may facilitate the removal, but would hinder the spleen weight estimation.

Laparoscopy permitted an improved visualization and identification of abdominal organs. This advantage is due to image amplification and improved illumination in videosurgery (Remedios \& Fergunson 1996). Nevertheless, the conventional technique permitted complete exposition of the spleen outside the abdominal cavity and thereby the best visualization of the splenic hilum.

The finding of less blood loss in laparoscopic surgery in this study differs from the findings in human splenectomies (Domini et al. 1999, Marassi et al. 1999), although it is consistent with a study in laparoscopic ovariohysterectomy in dogs, when compared to the conventional procedure (Malm et al. 2004). Lesser blood loss in our study is probably related to lesser tissue damage in the abdominal wall, and better vascular sealing visualization during the bipolar electrocoagulation.

Rectal temperature change due to laparoscopy is controversial in humans (Luck et al. 1999, Berber et al. 2001, Cohen et al. 2003) and little information in animals is available in this subject. Our results suggest that the pneumoperitoneum in not an important cause of hypothermia, and the lower rectal temperatures found in laparoscopy is related to longer surgical time.

Postoperatively increased hepatic enzymes are documented in both, humans (Morino et al. 1998, Nguyen et al. 2003, Marakis et al. 2006) and dogs (Nesek-Adam et al. 2004), submitted to laparoscopy. The significant increase in ALP in the laparoscopic group and a tendency of increase in ALT (although not significant) should be related to a decrease in portal venous flow since the intraabdominal pressure used in this study $(12 \mathrm{mmHg})$ is superior to portal venous pressure $(7-10 \mathrm{mmHg})$. Another possibility is the direct compressive effect of pneumoperitoneum in the liver (Tan et al. 2003, Nesek-Adam et al. 2004). Despite the increase in hepatic enzymes, the serum concentrations are in the normal value range (González et al. 2001). No animal presented clinical signs of hepatic disease, and it is in accord with Nesek-Adam et al. (2004) who suggest absence of clinical significance.

CK is considered an excellent marker of muscle damage, and an increased seric activity is can be observed in reversible lesion or muscle necrosis (Lopes et al. 2005). The elevation of CK concentration observed in this study can be related to the abdominal wall and diaphragm distention due to pneumoperitoneum (The Japanese Association of Abdominal Wall Lifting for Laparoscopic Surgery 1999). Subcutaneous or intravenous administration of drugs in our study followed the indication of Hancock et al. (2005) with an aim to avoid the enzyme increase due to intramuscular administration. In our study, lower CK concentration in the conventional group was contradictory to the findings of a comparative study between laparo- scopic and conventional ovariohysterec-tomy in dogs, which presented no significant differences (Hancock et al. 2005). According to Parent (2004), only concentrations higher than $10.000 \mathrm{U} / \mathrm{L}$ or $\geq 2.000 \mathrm{U} / \mathrm{L}$ persistent increase have clinical importance.

CRP is an acute phase protein, and increase in its concentration has been described after several surgical procedures in dogs. Its increase is proportional to the magnitude of trauma, thus being considered more useful than WBC in postoperative evaluation (Aka et al. 2004, Ceron et al. 2005, Rahr et al. 2006). The results found in this experiment suggest higher tissue damage in conventional surgery, as observed in studies in humans (Rorarius et al. 2001, Grande et al. 2002, Aka et al. 2004, Rahr et al. 2006). Similarity between CRP and WBC related to distribution curve was noted, although WBC apparently decreased later. CRP can be more accurate than neuroendocrine response in tissue damage evaluation because it is not affected by anesthetics like propofol and opioids (Rorarius et al. 2001).

The accurate determination of pain is difficult in animals. The lower punctuation in pain scale presented by laparoscopic access compared to conventional access in splenectomy was consistent with studies of pericardiectomy (Walsh et al. 1999) and ovariohysterectomy (Davidson et al. 2004, Hancock et al. 2005) in MIS in dogs.

Cortisol and glucose are considered stress markers, and have been found in lower concentrations in the postoperative period of endoscopic surgery in dogs, compared to conventional surgery (Walsh et al. 1999, Hancock et al. 2005). In the present study cortisol and glucose were not useful to evaluate pain, and show no difference between the procedures. The opioid and non-steroidal anti-inflammatory drugs should be contributed to postoperative pain control, being able to modulate neuroendocrine response and its biochemical markers (Rorarius et al. 2001).

The laparoscopic procedure presented an infection/ inflammation rate of surgical wounds six times lower than the conventional one. A small-sized incision, less tissue trauma, and less suture material used in the surgery might have contributed to this lower rate (Davidson et al. 2004). The classification suggested by Eugster et al. (2004) allowed a clearer comparison between the techniques, as well as the possibility of patronization and future comparison with the present study.

More intraabdominal adhesions occurred in dogs submitted to laparoscopy than to conventional surgery. It could be related to smaller abdominal wall lesions and lesser tissue manipulation (Schippers et al. 1998). The suppression of the metabolic response of peritoneum superficial cells due to exposure to $\mathrm{CO}_{2}$ can contribute to the reduction in adhesions (Polymeneas et al. 2001).

Ovariohysterectomy was performed during the visualization procedure of abdominal cavity, 30 days postoperatively and was not compromised by the adhesions. All the dogs were placed for adoption and the data of the owners were registered aiming at a long term follow up. 


\section{CONCLUSION}

The laparoscopic technique is suitable for splenectomy in dogs, presenting advantages in relation to blood loss, surgical stress and surgical wounds; however it requires more operative time and causes transitory increase in the liver and muscular enzymes.

\section{REFERENCES}

Aka N., Kose G., Gonenç I. \& Api M. 2004. Tissue trauma after vaginal hysterectomy and colporrhaphy versus abdominal hysterectomy: A randomized controlled study. Aust. N. Z. J. Obstet. Gynaecol. 44:328331.

Aziz O., Athanasiou T., Tekkis P.P., Purkayastha S., Haddow J., Malinovski V., Paraskeva P. \& Darzi A. 2006. Laparoscopic versus open appendectomy in children: a meta-analysis. Ann. Surg. 243:17-27.

Berber E., String A., Garland A., Engle K.L., Kim K.M., Ituarte P. \& Siperstein A.E. 2001. Intraoperative thermal regulation in patients undergoing laparoscopic vs open surgical procedures. Surg. Endosc. 15:281-285.

Braga M., Vignali A., Zuliani W., Frasson M., Di Serio C. \& Di Carlo V. 2005. Laparoscopic versus open colorectal surgery: cost-benefit analysis in a single-center randomized trial. Ann. Surg. 242:890-296

Brodsky J.A., Brody F.J., Walsh R.M., Malm J.A. \& Ponsky J.L. 2002. Laparoscopic splenectomy. Surg. Endosc. 16:851-854.

Cerón J.J., Eckersall P.D. \& Martinez-Subiela S. 2005. Acute phase protein in dogs and cats: Current knowledge and future perspectives. Vet. Clin. Pathol. 34:85-99.

Cohen R.V., Pinheiro Filho J.C., Schiavon C.A. \& Correa J.L.L. 2003. Alterações sistêmicas e metabólicas da cirurgia laparoscópica. Revta Bras. Videoc. 1:77-81.

Davidson E.B., Moll H.D. \& Payton M.E. 2004. Comparison of laparoscopic ovariohysterectomy and ovariohysterectomy in dogs. Vet. Surg. 33:62-69.

Donini A., Baccarani U., Terrosu G., Corno V., Ermacora A., Pasqualucci A. \& Bresadola F. 1999. Laparoscopic vs open splenectomy in the management of hematologic diseases. Surg. Endosc. 13:1220-1225.

Eugster S., Schawalder P., Gaschen F. \& Boerlin P. 2004. A prospective study of postoperative surgical site infections in dog and cats. Vet. Surg. 33:542-550.

Firth A.M. \& Haldane S.L. 1999. Development of scale to evaluate postoperative pain in dog. J. Am. Vet. Med. Assoc. 214:651-659.

Fraser S.A., Feldman L.S., Stanbridge D. \& Fried G.M. 2005. Characterizing the learning curve for a basic laparoscopic drill. Surg. Endosc. 19:1572-1578.

Freeman L.J. \& Potter L. 1998. Minimally invasive surgery of the hemolymphatic system, p.192-204. In: Freeman L.J. (Ed.), Veterinary Endosurgery. Mosby, St Louis.

González F.H.D., Carvalho V., Möller V.A. \& Duarte F.R. 2001. Perfil bioquímico sangüíneo de cães e gatos na cidade de Porto Alegre, Rio Grande do Sul, Brasil. Arq. Fac. Vet. UFRGS 29:1-6.

Grande M., Tucci G.F., Adorisio O., Barini A., Rulli F., Neri A., Franchi F. \& Farinon A.M. 2002. Systemic acute-phase response after laparoscopic and open cholecystectomy. Surg. Endosc. 16:313-316.

Hancock R.B., Lanz O.I., Waldron D.R., Duncan R.B., Broadstone R.V., Hendrix P.K. 2005. Comparison of postoperative pain after ovariohysterectomy by harmonic scalpel-assisted laparoscopy compared with median celiotomy and ligation in dogs. Vet. Surg. 34:273-382.

Harari J. 1999. Baço, p.244-248. In: Harari J. (Ed.), Cirurgia de Pequenos Animais. Artes Médicas Sul, Porto Alegre.

Härkki-Siren P., Sjöberg J. \& Kurki T. 1999. Major complications of laparoscopy: A follow-up Finnish study. Obstet. Gynecol. 94:94-98.
Higashihara E., Baba S., Nakagawa K., Murai M., Go H., Takeda M., Takahashi K., Suzuki K., Fujita K., Ono Y., Ohshima S., Matsuda T., Terachi T. \& Yoshida O. 1998. Learning curve and conversion to open surgery in cases of laparoscopic adrenalectomy and nephrectomy. J. Urol. 159:650-653.

Himal H.S. 2002. Minimally invasive (laparoscopic) surgery: The future of general surgery. Surg. Endosc. 16:1647-1652.

Hosgood G., Bone D.L., Vorhees W.D. \& Reed W.M.. 1989. Splenectomy in the dog by ligation of the splenic and short gastric arteries. Vet. Surg. 18:110-113.

Hutter M.M., Randall S., Khuri S.F., Henderson W.G., Abbott W.M. \& Warshaw A.L. 2006. Laparoscopic versus open gastric bypass for morbid obesity: a multicenter, prospective, risk-adjusted analysis from the National Surgical Quality Improvement Program. Ann. Surg. 243: 657-666.

Katkhouda N., Mason R.J., Towfigh S., Gevorgyan A. \& Essani R. 2005. Laparoscopic versus open appendectomy: a prospective randomized double-blind study. Ann. Surg. 242:439-450.

Lopes S.T.A., Franciscato C., Teixeira L.V., Oliveira T.G.M., Garmatz B.C., Veiga A.P.M. \& Mazzanti A. 2005. Determinação da creatina quinase em cães. Revta FZVA, Uruguaiana, 12:31-37.

Luck A.J., Moyes D., Maddern G.J. \& Hewett P.J. 1999. Core temperature changes during open and laparoscopic colorectal surgery. Surg. Endosc. 13:480-483.

Malm C., Savassi-Rocha P.R., Gheller V.A., Oliveira H.P., Lamounier A.R. \& Foltyneck V. 2004. Ovário-histerectomia: estudo experimental comparativo entre as abordagens laparoscópicas e convencionais na espécie canina. Intra-operatório. I. Arq. Bras. Med. Vet. Zootec. 56:457466.

Maluenda G.F., Burdiles P.P., Braghetto M.I. \& Csendes J.A. 2004. Esplenectomía laparoscópica en enfermedades hematológicas. Revta Méd. Chile 132:189-194.

Marakis G., Pavlidis T., Ballas K., Rafailidis S., Psarras K., Symeonidis N., Triantafyllou A. \& Sakantamis A. 2006. Alterations in liver functions test following laparoscopic cholecystectomy. Internet J. Surg. 8. Acess in: <http://www.ispub.com/journal/the_internet_journal_of_surgery >. Downloaded in March 3, 2009.

Marassi A., Vignali A., Zuliani W., Biguzzi E., Bergamo C., Gianotti L. \& Di Carlo V. 1999. Splenectomy for idiopathic thrombocytopenic purpura: Comparison of laparoscopic and conventional surgery. Surg. Endosc. 13:17-20.

Moberg A.C. \& Montgomery A. 2005. Primary access-related complications with laparoscopy: Comparison of blind and open techniques. Surg. Endosc. 19:1196-1199.

Morino M., Giraudo G. \& Festa V. 1998. Alterations in hepatic function during laparoscopic surgery. Surg. Endosc. 12:968-972.

Nesek-Adam V., Rasic Z., Kos J. \& Vnuk D. 2004. Aminotransferases after experimental pneumoperitoneum in dogs. Acta Anaesthesiol. Scand. 48:862-866.

Nguyen N.T., Braley S., Fleming N.W., Lambourne L., Rivers R. \& Wolfe B.M. 2003. Comparison of postoperative hepatic function after laparoscopic versus open gastric bypass Am. J. Surg. 186:40-44.

Oliveira A.L.A., Zorrón R., Queiroz M.R., Antunes F., Pires Neto M.A. \& Costa A.C. 2007. Esplenectomia videolaparoscópica em modelo canino: técnicas e indicações. Revta Bras. Med. Vet. 29:78-92.

Parent J. 2004. Neurologic Disorders, p.322-331. In: Willard M.D. \& Tvedten $\mathrm{H}$. (Eds) Small animal clinical diagnosis by laboratory methods. W.B. Saunders, St Louis.

Polymeneas G., Theodosopoulos T., Stamatiadis A. \& Kourias E. 2001. A comparative study of postoperative adhesion formation after laparoscopic vs open cholecystectomy. Surg. Endosc. 15:41-43.

Rahr H.B., Bendix J., Ahlburg P., Gjedsted J., Funch-Jensen P. \& Tønnesen E. 2006. Coagulation, inflammatory, and stress responses 
in a randomized comparison of open and laparoscopic repair of recurrent inguinal hernia. Surg. Endosc. 20:468-472.

Remedios A.M. \& Fergunson J. 1996. Minimally invasive surgery: Laparoscopy and thoracoscopy in small animals. Comp. Cont. Educ. Pract. Vet. 18:1191-1199.

Richter S., Kollmar O., Schilling M.K., Pistorius G.A. \& Menger M.D. 2006. Efficacy and quality of vessel sealing: Comparison of a reusable with a disposable device and affects of clamp surface geometry and structure. Surg. Endosc. 20:890-894.

Romano F., Caprotti R., Franciosi C., De Fina S., Colombo G. \& Uggeri F. 2002. Laparoscopic splenectomy using ligasure: Preliminary experience. Surg. Endosc. 16:1608-1611.

Rorarius M.G., Kujansuu E., Baer G.A., Suominen P., Teisala K., Miettinen A., Ylitalo P. \& Laippala P. 2001. Laparoscopically assisted vaginal and abdominal hysterectomy: Comparison of postoperative pain, fatigue and systemic response. Eur. J. Anaesthesiol. 18:530539.

Sapucahy M.V., Faintuch J., Bresciani C.J.C., Bertevello P.L., HabrGama A. \& Gama-Rodrigues J.J. 2003. Laparoscopic versus open splenectomy in the management of hematologic diseases. Revta Hosp. Clin. 58:243-249.

Schiochet F. 2006. Ovário-salpingo-histerectomia laparoscópica eletiva em felinos. Dissertação de Mestrado em Ciências Veterinárias, Programa de Pós-Graduação em Ciências Veterinárias, Universidade Federal do Rio Grande do Sul, Porto Alegre, RS. 91p.

Schippers E., Tittel A., Ottinger A. \& Schumpelick V. 1998. Laparoscopy versus laparotomy: Comparison of adhesion-formation after bowel resection in a canine model. Dig. Surg. 15:145-147.

Stedile R., Beck C.A.C., Schiochet F., Araújo A.C.P., Pinto V., Oliveira S.T., Contesini E.A., Seitz A.L., Dreimeier D., Santos Júnior E.B., Oliveira E.C., Rozza D.B., Pöppl A.G. \& Yamazaki P.H. 2004. Esplenectomia laparoscópica em cão: relato de caso. Anais do Congresso de Videocirurgia Veterinária, Porto Alegre, RS, p.32. (Resumo). Acess in: <http://www.ufrgs.br/medanimal/anais.pdf>. Downloaded in March 3, 2009.

Tan M., Xu F.F., Peng J.S., Li D.M., Chen L.H., Lv B.J., Zhao Z.X., Huang C. \& Zheng C.X. 2003. Changes in the level of serum liver enzymes after laparoscopic surgery. World J. Gastroenterol. 9:364367.

The Japanese Association of Abdominal Wall Lifting for Laparoscopic Surgery. 1999. Comparison between $\mathrm{CO}_{2}$ insufflation and abdominal wall lift in laparoscopic cholecystectomy: a prospective multiinstitucional study in Japan. Surg. Endosc. 13:705-709.

Van Goethem B.E., Rosenveldt K.W. \& Kirpensteijn J. 2005. Monopolar versus bipolar electrocoagulation in canine laparoscopic ovariectomy: A nonrandomized, prospective, clinical trial. Vet. Surg. 32:464-470.

Van Nimwegen S.A., Van Swol C.F. \& Kirpensteijn J. 2005. Neodymium: yttrium aluminum garnet surgical laser versus bipolar electrocoagulation for laparoscopic ovariectomy in dogs. Vet. Surg. 34:353-357.

Walsh R.M., Chand B., Brodsky J. \& Heniford B.T. 2003. Determination of intact splenic weight based on morcellated weight. Surg. Endosc. 17:1266-1268. 